\title{
Trace Dosing Unit
}

National Cancer Institute

\section{Source}

National Cancer Institute. Trace Dosing Unit. NCI Thesaurus. Code C48547.

An extremely small amount. 